\title{
Reduction of shadow band synthesis during PCR amplification of repetitive sequences from modern and ancient DNA
}

\section{Wera M.Schmerer}

\section{Introduction}

Repetitive sequences like short tandem repeat (STR) loci are generally referred to as slippery DNA (1). They owe this nickname to a characteristic leading to slippage within the primer-template complex during PCR elongation of the new strand (2,3), resulting in the synthesis of byproducts shortened by one repeat unit compared with the original sequence. The generation of these so-called shadow bands (4) is a well-known problem connected with the amplification of repetitive DNA, complicating the genotype analysis of modern (e.g., ref. 5), forensic (6), and ancient $(\mathbf{7 , 8 )}$ specimens. In some applications, the occurrence of this artifact makes it necessary to develop guidelines for allele designation $(6,9)$.

The intensity of these byproducts increases with the degradation of the target DNA $(\mathbf{8}, \mathbf{1 0})$, and therefore represents a particular problem concerning the analysis of highly degraded DNA as in genotyping of forensic (e.g., refs. 11,12) and ancient DNA (7,13,14). In amplification products of highly degraded or ancient DNA, the intensity of a shadow band can exceed the peak height or band intensity of the original allele. As artifact alleles $(7,15)$ they can lead to mistyping of amplification products (cf. also refs. 8,16). Because an amplification product is not necessarily affected in each case, this phenomenon can even result in seemingly different genotypes for independent amplification products of the same sample $(7,15,16)$.

To improve the reproducibility of amplification results and consequently decrease the probability of mistyping by reducing the generation of this artifact, the optimization of the PCR amplification process itself represents the most important strategy besides optimization of the extraction of the DNA used as template (17-19).

The findings presented in the following resulted from a study within the scope of which different strategies to optimize PCR amplification of repetitive DNA were investigated with reference to their effect on the generation of shadow bands (cf. ref. 19 Schmerer, manuscript in preparation). The model locus investigated was HUMVWA31/A (20), the amplifications of which show a high tendency to accumulate shadow bands compared with other STR loci $(11,12,21)$. Amplifications were performed on DNA Thermal Cycler (TC1, Perkin-Elmer Cetus). For a detailed presentation of the investigation concerned, please refer to Schmerer (19) and Schmerer (manuscript in preparation). 


\section{Materials}

1. InViTAQ ${ }^{\circledR}$ DNA polymerase (Invitek).

2. $\mathrm{NH}_{4}$ reaction buffer (Invitek). 10x buffer: $160 \mathrm{mM}\left(\mathrm{NH}_{4}\right)_{2} \mathrm{SO}_{4}, 500 \mathrm{mM}$ Tris- $\mathrm{HCl}$ $\left(\mathrm{pH} 8.3\right.$ at $\left.25^{\circ} \mathrm{C}\right)$, Tween $^{\circledR} 20$.

3. Betaine (3 M solution with sterile water also used for set up of the reaction mix).

4. Betaine (2 M) $+10 \%$ dimethyl sulfoxide (DMSO; solution with sterile water).

5. Bovine serum albumin (BSA; $125 \mu \mathrm{g} / \mathrm{mL}$ solution with sterile water).

6. INTP-mix composed according to the sequence amplified (e.g., for HUMVWA31/A with a $A / T: G / C$ ratio of 1.9:1, a stock of $121 \mu \mathrm{M}$ each of dGTP, dCTP, and 220 $\mu \mathrm{M}$ each of $d A T P$ and dTTP were used).

\section{Methods}

Each of the following variations of a standard PCR amplification protocol resulted in reduced accumulation of shadow bands. They might be applied either soldiery or in any combination.

\subsection{Denaturation Time}

A reduction of denaturation time to 15 to 30 s results in a $28 \%$ decrease in shadow bands compared with the standard denaturation time of $1 \mathrm{~min}$ by decreasing the occurrence of additional degradation of the template DNA (cf. ref. 22) because of the shorter incubation period at the high temperature of $94^{\circ}$ C.

\subsection{Elongation Step}

Applying an elongation time of $1 \mathrm{~min}$, which is the standard used for synthesis of a PCR product up to $1 \mathrm{~kb}$, the lowest intensity of shadow bands was found with an elongation temperature of $68^{\circ} \mathrm{C}$, resulting in a $20.4 \%$ reduction compared with the generally applied temperature of $72^{\circ} \mathrm{C}$. This reduction could be even increased to $24.7 \%$ by doubling the time for synthesis. The highest reduction of the generation of this artefact $(-30.9 \%)$ could be achieved with an elongation at $70^{\circ} \mathrm{C}$ for $2 \mathrm{~min}$.

\subsection{Polymerase and Composition of Reaction Buffer}

Comparing different polymerases and polymerase mixes respective, the lowest intensity of shadow bands was observed with InViTAQ ${ }^{\circledR}$ (Invitek) and the CombiPoil $^{\circledR}$ polymerase mix (Invitek) in combination with OptiPerform ${ }^{\mathrm{TM}}$ Buffer (Invitek) with a reduction of the artefact by up to 24 and $21.4 \%$ compared with AmpliTaq ${ }^{\mathrm{TM}}$ Gold (Perkin-Elmer) in combination with GeneAmp ${ }^{\circledR}$ buffer (Perkin-Elmer). Applying InViTaq, a replacement of the generally used KCl-reaction buffer, by an optimized

$\mathrm{NH}_{4}$ buffer resulted in a $22 \%$ reduction in artefact accumulation applying the same polymerase. Further differences of the two buffer systems consist in a slightly elevated

pH value of $8.8(+0.5)$ and an addition of $0.01 \%$ Tween-20 in case of the $\mathrm{NH}_{4}$ buffer.

The use of a polymerase displaying a $3^{\prime} \rightarrow 5^{\prime}$ exonuclease proof-reading ability showed no positive effects concerning the reduction of shadow band accumulation, neither applied alone, nor in combination with a Taq polymerase. 


\subsection{A/T : G/C Ratio of the dNTP-Mix}

Changing the composition of the dNTP-mix from the usual equimolar concentration of nucleotides to a $A / T: G / C$ ratio of 1.9:1 corresponding to the composition of the general sequence of HUMVWA31/A, the locus amplified, resulted in a decrease in shadow band generation by $7.3 \%$. Changes in amplification efficiency were not observed, neither in processing modern nor ancient DNA. Equability of the amplifica-tion of both alleles belonging to a heterozygous genotype was slightly improved.

\subsection{Betaine ( N,N,N-trimethyl glycine)}

The presence of betaine in a concentration of 0.5 to $2 \mathrm{M}$ reduced the accumulation of shadow bands, with a maximum reduction of $15.5 \%$ at $0.5 \mathrm{M}$. Concentrations lower than 0.5 showed an increase in artifact production. Concerning the amplification of ancient DNA, low concentrations of betaine $(0.25-1 \mathrm{M})$ resulted in an increase in product yield because of the neutralizing effect of this reagent against inhibitory substances (cf. ref. 23) frequently present within ancient DNA extracts. Beyond $1.5 \mathrm{M}$, an addition of the inhibitory effect of betaine at elevated concentrations (24) and the inhibition caused by co-extracted impurities occurred, resulting in partial inhibition of amplification.

\subsection{Betaine Combined with DMSO}

Like betaine, low concentrations of both betaine and DMSO resulted in a slight increase in intensity of shadow bands. A reduction of the artifact was observed at concentrations of 0.4 to $1 \mathrm{M}$ betaine combined with 2 to $5 \%$ DMSO, with a maximum decrease of shadow band intensity by $12.6 \%$ at 0.8 M betaine and 4\% DMSO. In ancient DNA amplifications, the presence of these reagents increased product yield and reproducibility between multiple amplifications of the same sample (see Note 1).

\subsection{BSA}

The addition of BSA in a concentration of 10 to $25 \mu \mathrm{g} / \mathrm{mL}$ resulted in reduced intensity of artifact bands with a maximum at $25 \mu \mathrm{g} / \mathrm{mL}$ by $21.2 \%$ accompanied by an increased equability of amplification of a heterozygote genotype. In addition to this, the presence of BSA showed to increase the efficiency of ancient DNA amplifications by neutralizing inhibitory substances (25) that consequently resulted in higher yield of specific product. A concentration of 25 to $50 \mu \mathrm{g} / \mathrm{mL}$ was determined as optimal for the amplification of ancient DNA. 


\section{Notes}

1. Also investigated concerning their impact in the generation of shadow bands were further reagents commonly used as PCR-enhancing additives, such as DMSO, glycerol, and formamide. In amplifications of the locus concerned the addition of DMSO, as well as formamide in different concentrations resulted in an increase in shadow band accumula-tion. Glycerol, however, did not show any effect, neither on modern, nor ancient DNA amplification. 


\section{References}

1. Kunkel, T. A. (1993) Nucleotide repeats. Slippery DNA and diseases. Nature 365, 207-208.

2. Levison, G. and Gutman, G. A. (1987) Slipped-strand mispairing: a mayor mechanism for DNA sequence evolution. Mol. Biol. Evol. 4, 203-221.

3. Schlötterer, C. and Tautz, D. (1992) Slippage synthesis of simple sequence DNA. Nucleic Acids Res. 20, 211-215.

4. Weber, J. L. and May, P. E. (1989) Abundant class of human polymorphisms which can be typed using the polymerase chain reaction. Am. J. Hum. Genet. 44, 388396.

5. Bluteau, O., Legoix, P., Laurent-Puig, P., and Zucman-Rossi, J. (1999) PCR-based genotyp-ing can generate artifacts in LOH analyses. BioTechniques 27, 1100 1102.

6. Gill, P., Sparkes, R., and Kimpton, C. (1997) Development of guidelines to designate alleles using a STR multiplex system. Forensic Sci. Int. 89, 185-197.

7. Schmerer, W. M., Hummel, S., and Herrmann, B. (1997) Reproduzierbarkeit von aDNA-typing. Anthrop. Anz. 55, 199-206.

8. Ivanov, P. L. and Isaenko, M. V. (1999) Identification of human decomposed remains using the STR systems: effect on typing results, in Proceedings of the second European symposium on human identification 1998. Promega Corporation, Innsbruck, Austria.

9. Fourney, R. M., Fregau, C. J., Bowen, J. H., Bowen, K. L., Shutler, G. G., Elliot, J. C., et al.(1995) Interpretation guidelines for fluorescent automated detection of STRs: Defining the allele and the limits of detection, in Proceedings from the Sixth International Symposium on Human Identification 1995. Promega Corporation, Innsbruck, Austria.

10. Murray, V., Monchawin, C., and England, P. R. (1993) The determination of the sequences present in the shadow bands of a dinucleotide repeat PCR. Nucleic Acids Res. 21, 2395-2398.

11. Kimpton, C., Fisher, D., Watson, S., Adams, M., Urquhard, A., Lygo, J., et al. (1994) Evaluation of an automated DNA profiling system employing multiplex amplification of four tetrameric STR loci. Int. J. Leg. Med. 106, 302-311.

12. Lygo, J. E., Johnson, P. E., Holaway, D. J., Woodroffe, S., Whitaker, J. P., Clayton, T. M., et al. (1994) The validation of short tandem repeat (STR) loci for use in forensic casework. Int. J. Leg. Med. 107, 77-89.

13. Ramos, M. D., Lalueza, C., Girbau, E., Perez-Perez, A., Quevedo, S., Turbon, $D$., et al.(1995) Amplifying dinucleotide microsatellite loci from bone and tooth samples of up to 5000 years of age: More inconsistency than usefulness. Hum. Genet. 96, 205-212.

14. Schultes, T., Hummel, S., and Herrmann, B. (1997) Recognizing and overcoming inconsis-tencies in microsatellite typing of ancient DNA samples. Ancient Biomol. 1, 227-233.

15. Schmerer, W. M. (1996) Reproduzierbarkeit von Mikrosatelliten-DNA-Amplifikation und Alleldetermination aus bodengelagertem Skelettmaterial. Unpublished diploma-thesis, Göttingen.

16. Taberlet, P., Griffin, S., Goossens, B., Questiau, S., Manceau, V., Escaravage, N., et al.(1996) Reliable genotyping of samples with very low DNA quantities using PCR. Nucleic Acids Res. 24, 3189-3194.

17. Schmerer, W. M., Hummel, S., and Herrmann, B. (1999) Optimized DNA extraction to improve reproducibility of short tandem repeat genotyping with highly degraded DNA as target. Electrophoresis 20, 1712-1716.

18. Schmerer, W. M., Hummel, S., and Herrmann, B. (2000) STR-genotyping of archaeological human bone: Experimental design to improve reproducibility by optimisation of DNA extraction. Anthrop. Anz. 58, 29-35. 
19. Schmerer, W. M. (2000) Optimierung der STR-Genotypenanalyse an Extrakten alter DNA aus bodengelagertem menschlichen Skelettmaterial. Cuvillier Verlag, Göttingen.

20. Kimpton, C. P., Walton, A., and Gill, P. (1992) A further tetranucleotide repeat polymor-phism in the vWF gene. Hum. Mol. Genet. 1, 287.

21. Bacher, J. and Schumm, J.W. (1998) Development of highly polymorphic pentanucleotide tandem repeat loci with low stutter. Profiles DNA 2, 3-6.

22. Cheng, S., Fockler, C., Barnes, W. M., and Higuchi, R. (1994) Effective amplification of long targets from cloned inserts and human genomic DNA. Proc. Natl. Acad. Sci. USA 91, 5695-5699.

23. Baskaran, N., Kandpal, R. P., Bhargava, A. K., Glynn, M. W., Bale, A., and Weissman, S. M.(1996) Uniform amplification of a mixture of deoxyribonucleic acids with varying GC content. Genome Res. 6, 633-638.

24. Weissensteiner, T. and Lanchbury, J. S. (1996) Strategy for controlling preferentiual amplification and avoiding false negatives in PCR Typing. Biotechniques 21, 1102-1108.

25. Pääbo, S., Gifford, J. A., and Wilson, A. C. (1988) Mitochondrial DNA sequences from a 7000-year old brain. Nucleic Acids Res. 20, 9775-9787. 